\title{
Dynamic Modeling, Control, and Analysis of a Solar Water Pumping System for Libya
}

\author{
Muamer M. Shebani and Tariq Iqbal \\ Department of Electrical and Computer Engineering, Faculty of Engineering and Applied Science, \\ Memorial University of Newfoundland, St. John's, NL, Canada \\ Correspondence should be addressed to Muamer M. Shebani; mms137@mun.ca
}

Received 9 November 2016; Revised 7 March 2017; Accepted 14 March 2017; Published 24 April 2017

Academic Editor: Pallav Purohit

Copyright (C) 2017 Muamer M. Shebani and Tariq Iqbal. This is an open access article distributed under the Creative Commons Attribution License, which permits unrestricted use, distribution, and reproduction in any medium, provided the original work is properly cited.

\begin{abstract}
In recent years, one of the suitable solar photovoltaic (PV) applications is a water pumping system. The simplest solar PV pumping system consists of PV array, DC-DC converter, DC motor, and water pump. In this paper, water pumping system sizing for Libya is evaluated based on a daily demand using HOMER software, and dynamic modeling of a solar PV water pumping system using a Permanent Magnet DC (PMDC) motor is presented in Matlab/Simulink environment. The system performance with maximum power point tracking (MPPT) based on Fractional Open Circuit Voltage (FOCV) is evaluated with and without a battery storage system. In some applications, a rated voltage is needed to connect a PMDC motor to a PV array through a DC-DC converter and in other applications the input voltage can vary. The evaluation of the system is based on the performance during a change in solar irradiation. Using Matlab/Simulink, simulation results are assessed to see the efficiency of the system when it is operating at a specific speed or at the MPPT. The results show that an improvement in the system efficiency can be achieved when the PMDC motor is running at a specific speed rather than at the peak PV power point.
\end{abstract}

\section{Introduction}

In rural areas, standalone photovoltaic water pumping systems have become very competitive solution for water supply because the access to an electric grid is not available or costly effective. In Libya, standalone solar systems are gaining more interest than other renewable energy sources because many sunny days are available. Moreover, because of the environment issues such as global warming, researchers are led to develop the renewable energy sources such as solar systems.

One of the most important issues with PV standalone systems is its efficiency and performance over various operating conditions. In [1] a brushless DC motor solar water pumping system is described and simulated. The system model is developed from an individual component to assess the overall performance of the system. The results show that the efficiency of solar PV water pumping system over various operating conditions is improved compared to the existing systems. The performance of standalone solar systems is also associated with the parallel and series combination of PV module. In [2] a simulated model of directly connected solar PV system to a PMDC motor water pumping system and its experimental results are carried out and analyzed. For different solar irradiation and ambient temperature, a combination of series and parallel PV modules is analyzed in terms of their performance. The results show that a good matching cannot be achieved at low solar irradiation. A good matching can be achieved for a typical parallel and series combination of the PV module. Furthermore, the solar water pumping system performance is evaluated under fixed position and manual tracking of PV panel. The evaluation shows that the manual tracking for the water pumping system is $22.6 \%$ more efficient than the fixed PV panels.

Type of motor in standalone water pumping systems affects the overall system performance. In [3] a PV system, a permanent magnetic DC motor, and a single phase induction motor models are implemented in Matlab/Simulink environment. The use of PV system is to feed a water pumping system. A simulation and experimental results are carried out 
to evaluate the performance of the PMDC motor compared to the single phase induction motor. The result shows that the single phase induction motor has lower performance compared to the PMDC motor. The use of the PMDC motor to drive a water pump is simpler compared to using the single induction motor because the PMDC motor does not require an inverter and excitation system for its field. The performance of DC motor varies also according to its type. In [4] a comparative study based on Matlab simulation between a PMDC motor water pumping system and DC motor water pumping system is presented. The two systems are fed by a PV source whose power output varies according to the solar irradiation and ambient temperature. The result shows that the performance of a PMDC motor water pumping system is better.

Regulating water discharge of standalone solar water pumping systems during the variation of solar irradiation is one of the keys to assess their performance. In [5] a standalone solar PV water pumping system driven by a permanent magnetic synchronous motor (PMSM) is modeled in Matlab/Simulink environment. The PV system is connected to a boost converter to regulate and maintain the DC bus voltage at constant level. The three-phase voltage source inverter supplies the PMSM and it is controlled to regulate the water discharge during a variation of solar irradiation. The result shows that the performance of solar photovoltaic PMSM water pumping system provides a satisfied motor speed under a variation of solar irradiation.

Operating motor at maximum efficiency can enhance the overall efficiency of a solar water pumping system. In [6] a system that consists of a directly connected solar PV array to a Switched Reluctance Motor (SRM) driving a centrifugal water pump is presented. The system considers the SRM because its efficiency, reliability, and cost are comparative to the DC and AC conventional electric machine for this type of application. The system is mathematically modeled and simulated in Matlab environment. By controlling the motor input current, the solar PV array is operated at the point of extracting maximum power. For a set of different solar irradiation and ambient temperature, simulation results are carried out. The simplicity of the control system helps to achieve the maximum power point tracking of the PV system. This control demonstrates its achievement result through the dynamic simulation. However, in the case of induction motor water pumping system, the operation of the induction motor at its maximum efficiency is better than operating the solar PV array at its maximum power point to extract the peak power. In [7] a dynamic analysis and steady state operation of a water pumping system is presented. The water pumping system consists of an induction motor, a threephase voltage source inverter, and solar PV array. The threephase voltage inverter is controlled to achieve the maximum efficiency operation of the induction motor. The results show that the maximum efficiency of the induction motor and overall standalone solar system is achieved under a variation of the solar irradiation.

Improving efficiency of standalone solar water pumping systems can be achieved when a PV array operates at MPPT. In [8] photovoltaic DC motor water pumping system is
TABLE 1: Daily water requirement for some application.

\begin{tabular}{ll}
\hline Application & Approximation usage \\
\hline Each person, for all purposes & 50 gallons per day \\
Each milking cow & $20-30$ gallons per day \\
Each horse and every cattle & $10-15$ gallons per day \\
Each sheep and each goat & 2 gallons per day \\
Every 100 chickens & $6-12$ gallons per day \\
\hline
\end{tabular}

modeled and simulated in Matlab. A DC motor is used and driven by a solar PV source through a DC-DC converter. The model evaluates the performance of the system using actual irradiation data. The performance is examined using P\&O based MPPT algorithm and without MPPT algorithms. The performance parameters consider the produced power and the volume of the pumped water per day. The simulation results indicate that the system with $\mathrm{P} \& \mathrm{O}$ based MPPT algorithm has better efficiency and performance in comparison to the system without implementing the MPPT algorithm. However, the best performance for standalone water pumping systems without MPPT can be achieved with matching electromechanical characteristics of a motor and a solar PV array. In [9] theoretical and experimental results for a directly coupled solar PV water pumping system are presented. A centrifugal pump is driven by a PMDC motor which is directly connected to solar PV array. The experimental and simulation results are carried out based on a good match between the electromechanical characteristics of the PMDC motor and the solar PV array at various solar irradiation values. For low solar irradiation, the torque-speed curve should be steeper than the torque-speed curve for high solar irradiation. The performance of the simulated and experimented system is used for selecting a suitable PV array that has a good match with an electromechanical system.

This paper aims to achieve the highest efficiency of a standalone water pumping system by implementing MPPT and running a PMDC at the highest efficiency. By adding a storage battery system, the MPPT tracking can be implemented and the extra power can be stored. The water pumping system can run at specific speed to meet the daily demand for the specific location in Libya. At the same time the PMDC runs at the highest efficiency. The paper focuses on the performance of a directly coupled water pumping system with MPPT based on FOCV and compared it with the performance of solar water pumping system with a battery storage system. The comparison is based on the PMDC motor efficiency for a different scenario of rotor speed.

\section{System Sizing and Components}

The amount of water needed is the first step toward sizing a solar water pumping system. However, if the water needs are varying, the sizing should use the highest amount of water needs. Table 1 shows the approximated water usage per day. 


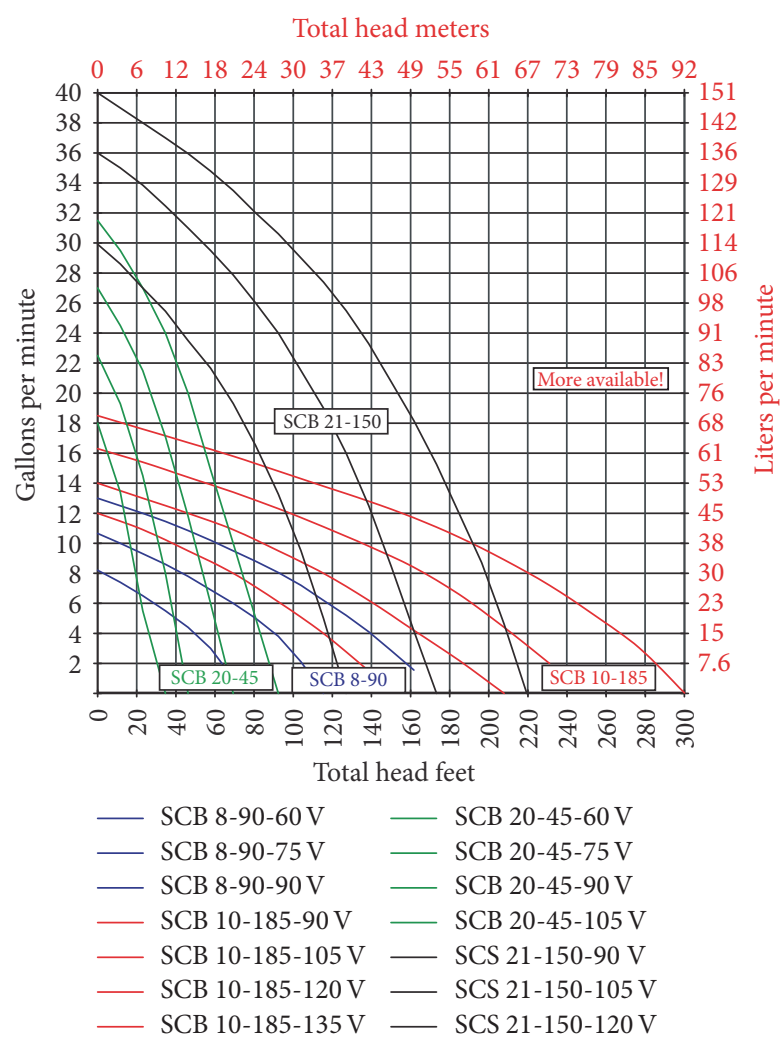

FIGURE 1: Centrifugal booster pump selection guide.

The solar water pumping system is designed in this paper to water the needs of a small farm. The needs of the farm are associated with a family of six people water needs, two milking cows, two horse, twenty sheep, ten goats, and five thousand chickens in Libya. From Table 1 and the daily water needs for the farm, the total daily water needs per day are 750 gallons/day.

The peak sun hours in Libya are 3000-3500 hours per year. As a result, the number of peak sun hours per day is nine hours per day. To sustain the daily watering needs, the proposed solar water pumping system has to be capable of pumping $(750 /(9 * 60))$ gallons per minute. This is about 1.4 gallons per minute. Because of the variation in the peak sun hours between the winter and the summer, the amount of 1.4 gallons per minute should be considered as minimum rate flow of water. To meet the requirement in winter, the amount of 2 gallons per minutes is suitable. The total depth of the well is $90 \mathrm{ft}$. Figure 1 shows the relationship between the total depth and the rate flow of the water for different type of centrifugal water pump.

The SCB $20-45$ at $105 \mathrm{~V}$ is chosen based on the water needs since the 2 gallons per minute is the goal of the water pumping system and the total depth is $90 \mathrm{ft}$. The power needs for water pump are $0.5 \mathrm{hp}$ driven by a PMC motor.

Table 2 indicates monthly averaged insolation incident on a horizontal surface $\left(\mathrm{kWh} / \mathrm{m}^{2} /\right.$ day) in Libya [10].

Since the electrical load is $0.37285 \mathrm{kw}(0.5 \mathrm{hp})$ which is approximately $0.4 \mathrm{~kW}$ and the number of peak sun hours
TABLE 2: Monthly averaged insolation incident $\left(\mathrm{kWh} / \mathrm{m}^{2} /\right.$ day $)$ in Libya.

\begin{tabular}{lc}
\hline Month & $\mathrm{kWh} / \mathrm{m}^{2} /$ day \\
\hline January & 4.426 \\
February & 5.361 \\
March & 6.199 \\
April & 6.846 \\
May & 7.376 \\
June & 7.877 \\
July & 7.878 \\
August & 7.450 \\
September & 6.695 \\
October & 5.784 \\
November & 4.621 \\
December & 4.142 \\
\hline
\end{tabular}

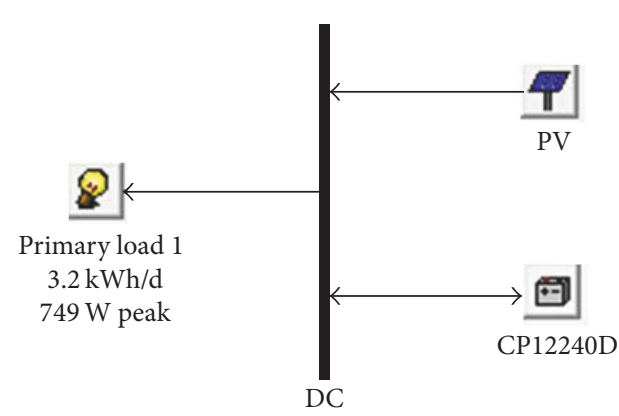

FIGURE 2: System implementation in Homer.

per day in Libya is nine hours per day, the Homer software (http://homerenergy.com) can be used to size the proposed water pumping system. Based on the Homer optimization result, the pump load needs fifteen $0.075 \mathrm{~kW}$ PV modules and sixteen batteries to sustain the daily watering needs. These results are based on the monthly averaged insolation incident on a horizontal surface $\left(\mathrm{kWh} / \mathrm{m}^{2} /\right.$ day) in Libya. Figure 2 shows the system implementation in Homer software.

The categorized result of the optimization analysis indicates that the rated PV array is $1.2 \mathrm{~kW}$ and the number of batteries needed is sixteen.

The PV module uses a single diode model which is shown in Figure 3. Depending on solar irradiation and ambient temperature, the output power from the PV module varies.

The mathematical modeling of a PV cell is described by (1)-(6). The output current (I) from the PV module is given as

$$
I=I_{\mathrm{PV}}-I_{D}-I_{\mathrm{SH}}
$$

where $I_{\mathrm{PV}}$ is the photon generated current from the PV module. $I_{\mathrm{PV}}$ is given as

$$
I_{\mathrm{PV}}=\frac{G}{G_{n}} *\left(I_{\mathrm{pv} n}+k_{i} *\left(T-T_{n}\right)\right),
$$

where $G$ is the actual solar irradiation, $G_{n}$ is the nominal irradiation at standard condition STC $1000 \mathrm{~W} / \mathrm{m}^{2}$ and $25^{\circ} \mathrm{C}$, 


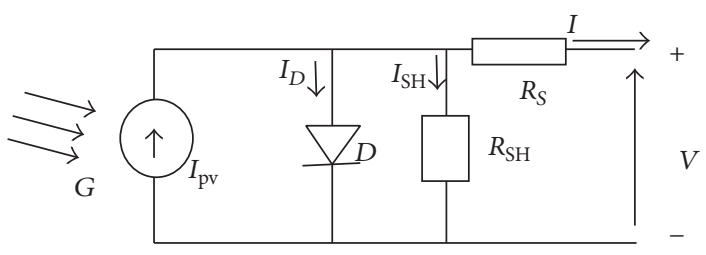

FIGURE 3: Single diode model of a solar cell.

TABle 3: Parameters of the ISOFOTON I-75 module at $25^{\circ} \mathrm{C}$ and $1000 \mathrm{~W} / \mathrm{m}^{2}$.

\begin{tabular}{lc}
\hline Parameters & Value \\
\hline Short circuit current $\left(I_{\text {sc }}\right)$ & $4.67 \mathrm{~A}$ \\
Open-circuit voltage $\left(V_{\text {oc }}\right)$ & $21.6 \mathrm{~V}$ \\
MPP current $\left(I_{\text {mpp }}\right)$ & $4.34 \mathrm{~A}$ \\
MPP voltage $\left(V_{\text {mpp }}\right)$ & $17.4 \mathrm{~V}$ \\
Temperature coefficient of $I_{\text {sc }}\left(k_{i}\right)$ & $0.0032 \mathrm{~A} / \mathrm{K}$ \\
Temperature coefficient of $V_{\text {oc }}\left(k_{v}\right)$ & $-0.01214 \mathrm{~V} / \mathrm{K}$ \\
Number of cells in series $\left(N_{s}\right)$ & 36 \\
Diode ideality factor $(a)$ & 1.3 \\
Series resistance $\left(R_{s}\right)$ & $0.15 \Omega$ \\
Parallel resistance $\left(R_{p}\right)$ & $163.59883 \Omega$ \\
\hline
\end{tabular}

$I_{\mathrm{pv} n}$ is the short circuit of the PV array at STC, $k_{i}$ is temperature coefficient of $I_{\mathrm{pv} n}, T$ is the actual temperature, and $T_{n}$ is $25^{\circ} \mathrm{C}$. The diode current $I_{D}$ is given by

$$
I_{D}=I_{r} *\left(\exp \left(\left(V+I * R_{s}\right) * V_{t a}\right)-1\right),
$$

where $I_{r}$ is the diode saturation current and it is given by (4) and $V_{t a}$ is given by (5):

$$
I_{r}=I_{\mathrm{rs}} *\left(\frac{T}{T_{n}}\right)^{3} \exp \left(q * \frac{E g}{K * a}\right) *\left(\frac{1}{T_{n}}-\frac{1}{T}\right),
$$

where $I_{\mathrm{rs}}$ is the diode reverse saturation current, $q$ is the charge of electron $\left(1.61 * 10^{-19} \mathrm{C}\right), K$ is Boltzmann's constant $\left(1.38 * 10^{-23} \mathrm{~J} / \mathrm{K}\right)$, and $a$ is the diode ideality factor.

$$
V_{t a}=\frac{q}{\left(a * N_{s} * K * T\right)}
$$

where $N_{s}$ is the number of series cells in the PV module. The diode reverse saturation current is given by

$$
I_{\mathrm{rs}}=\frac{k_{i} *\left(T-T_{n}\right) * I_{\mathrm{sc}}}{\exp \left(V_{\mathrm{oc}} * k_{v} *\left(T-T_{n}\right) V_{t a}\right)} .
$$

The characteristic of the PV module can be obtained by modeling (1)-(6) in Matlab/Simulink. The standard test condition $\left(1000 \mathrm{~W} / \mathrm{m}^{2}\right.$ and $\left.25^{\circ} \mathrm{C}\right)$ parameters for a ISOFOTON I-75 photovoltaic system is shown in Table 3.
TABLE 4: Operating values for the boost converter.

\begin{tabular}{lc}
\hline Parameters & Value \\
\hline Switching frequency $f$ & $25 \mathrm{kHz}$ \\
Inductance $L$ & $30 \mathrm{mH}$ \\
Capacitance $C$ & $200 \mu \mathrm{F}$ \\
Load resistance $R$ & $25 \Omega$ \\
\hline
\end{tabular}

Figure 4 shows the model of a ISOFOTON I-75 array in Matlab/Simulink. The ISOFOTON I-75 module is connected to a variable load resistance to examine the characteristic of the PV.

The $P-V$ curves for the PV array are shown in Figure 5. The model is simulated for various solar irradiation values which are $200 \mathrm{~W} / \mathrm{m}^{2}, 400 \mathrm{~W} / \mathrm{m}^{2}, 600 \mathrm{~W} / \mathrm{m}^{2}, 800 \mathrm{~W} / \mathrm{m}^{2}$, and $1000 \mathrm{~W} / \mathrm{m}^{2}$.

Figure 5 shows an increase in the PV array output power due to the increase in the solar irradiance. Figure 6 shows $V-I$ curves for the PV array. The results are carried out for various solar irradiance values. When the solar irradiance becomes higher, the PV array output is increased. As a result, the voltage across the PV output and the drawn current from the PV array becomes larger.

Figure 7 shows $P-V$ curves for the PV array at a different ambient temperature. As it is shown in Figure 7, the increase in ambient temperature decreases the output power of the PV array.

Figure 8 shows $I-V$ for the PV array at different ambient temperature.

Figure 8 indicates that the output voltage and current are lowered due to an increase in the ambient temperature.

\section{DC-DC Boost Converter}

The equivalent circuit of a boost converter is shown in Figure 9. The boost converter is connected to the photovoltaic array.

The parameters of the boost converter are shown in Table 4 . These parameters are determined according to the ripple limit $(\delta=1 \%)$ and by using the following expression:

$$
D=1-\frac{V_{\text {in }}}{V_{\text {out }}},
$$




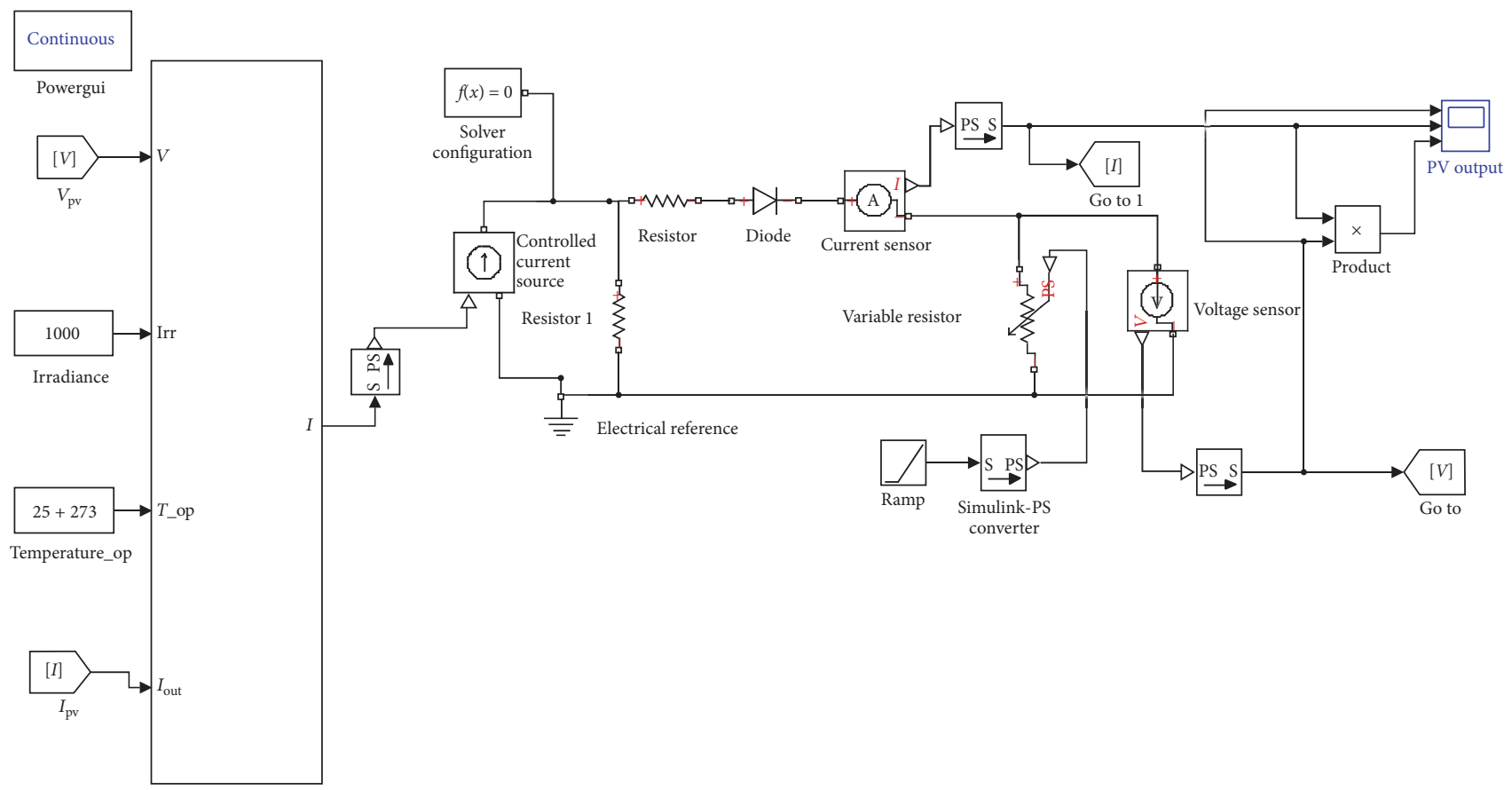

ISOFOTON I-75 PV model 54 cell in series

FIgURE 4: The model of a ISOFOTON I-75 array in Matlab/Simulink.

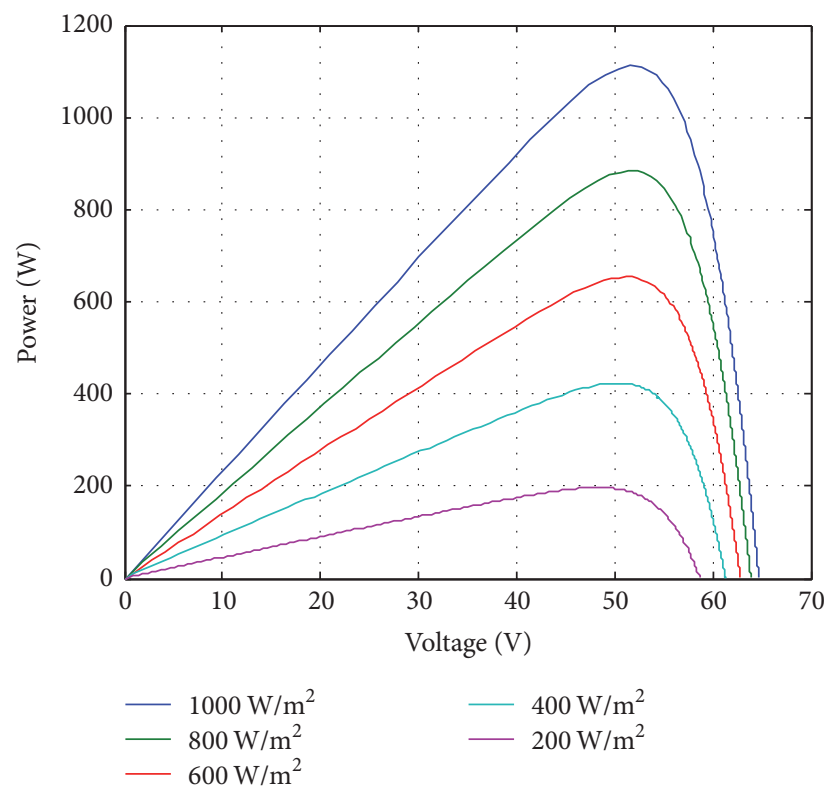

Figure 5: $P-V$ curves for PV array.

where $D$ is the duty ratio, $V_{\text {in }}$ is the input voltage, and $V_{\text {out }}$ is the output voltage. The inductance is calculated as

$$
L=\frac{\left(V_{\mathrm{in}} * D\right)}{\left(\delta * I_{\mathrm{in}} * f\right)}
$$

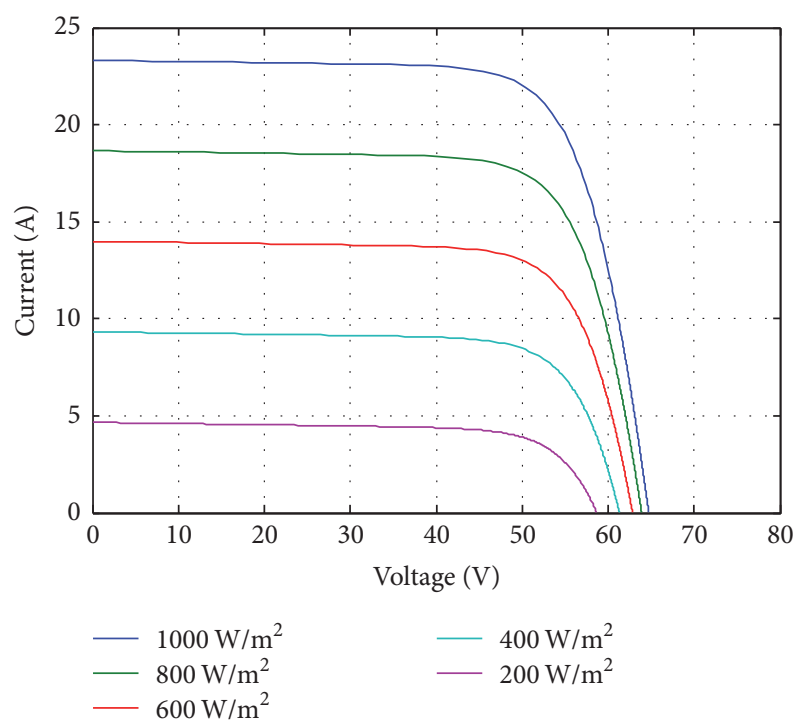

Figure 6: $I-V$ curves for PV array.

where $f$ is the switching frequency and $I_{\text {in }}$ is the input current. The capacitance is calculated as

$$
C=\frac{\left(I_{\text {out }} * D\right)}{\left(\delta * V_{\text {out }} * f\right)},
$$

where $I_{\text {out }}$ is the output current.

The DC-DC boost converter operates in continuous mode. There are two states of operation which are ON state and OFF state. During each state, a state of differential question is driven to describe the dynamic operation of the 


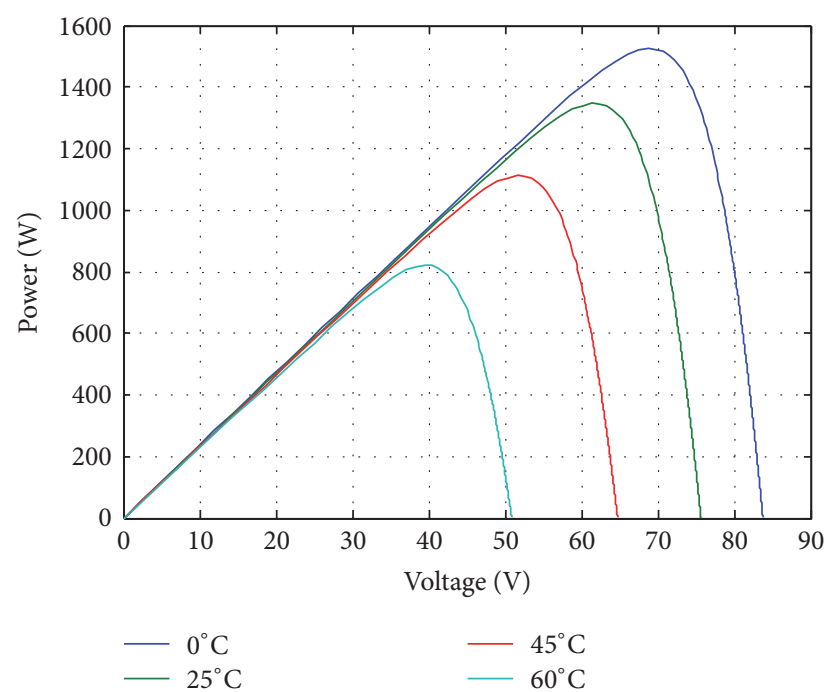

Figure 7: $P-V$ curves for PV array with different ambient temperature.

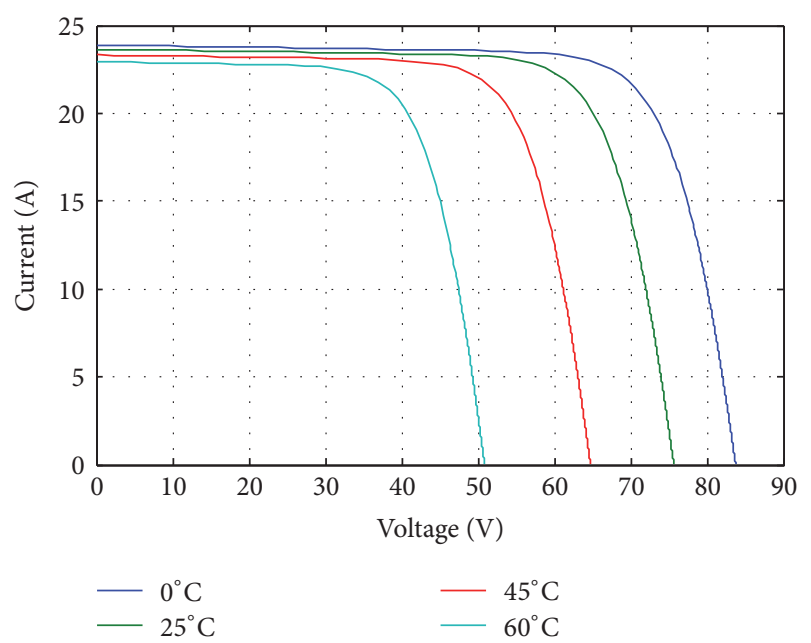

Figure 8: $I$ - $V$ curves for PV array with different ambient temperature.

boost converter. Equations (10) are the state space model for the boost converter during $\mathrm{ON}$ and OFF state of operation.

$$
\begin{aligned}
& {\left[\begin{array}{c}
\dot{i_{L}} \\
\dot{v}_{c}
\end{array}\right]=A_{1}\left[\begin{array}{l}
i_{L} \\
v_{c}
\end{array}\right]+B_{1} V_{\text {in }},} \\
& V_{\text {out }}=C_{1}\left[\begin{array}{l}
i_{L} \\
v_{c}
\end{array}\right], \\
& {\left[\begin{array}{c}
\dot{i_{L}} \\
\dot{v_{c}}
\end{array}\right]=A_{2}\left[\begin{array}{l}
i_{L} \\
v_{c}
\end{array}\right]+B_{2} V_{\text {in }},} \\
& V_{\text {out }}=C_{2}\left[\begin{array}{l}
i_{L} \\
v_{c}
\end{array}\right] .
\end{aligned}
$$

The matrices $A_{i}, B_{i}$, and, $C_{i}$ are given by

$$
\begin{aligned}
& A_{1}=\left[\begin{array}{cc}
0 & 0 \\
0 & \frac{-1}{R C}
\end{array}\right], \\
& A_{2}=\left[\begin{array}{cc}
0 & \frac{-1}{L} \\
\frac{1}{C} & \frac{-1}{R C}
\end{array}\right], \\
& B_{1}=B_{2}=\left[\begin{array}{c}
\frac{1}{L} \\
0
\end{array}\right], \\
& C_{1}=C_{2}=\left[\begin{array}{ll}
0 & 1
\end{array}\right] .
\end{aligned}
$$

The state space averaging technique is used. Therefore, the state vector $x(t)$ which is $\left[i_{L}(t) v_{c}(t)\right]$ is given as

$$
\begin{gathered}
\dot{x}(t)=A x+B u, \\
y=C x .
\end{gathered}
$$

The computation of $A$ matrix, $B$ matrix, and $C$ matrix is based on the state space averaging which is given as

$$
\begin{aligned}
& A=D A_{1}+(1-D) A_{2}, \\
& B=D B_{1}+(1-D) B_{2}, \\
& C=D C_{1}+(1-D) C_{2} .
\end{aligned}
$$

From the transfer function of the boost converter, the PI controller is determined using SISO tool in Matlab/Simulink. The transfer function of the converter is given as

$$
H(s)=\frac{0.543 * S^{2}+108.6 * S+9.507 * 10^{4}}{S^{2}+200 * S+3.481 * 10^{4}} .
$$

Also, the parameters of the PI controller are given as

$$
\mathrm{PI}=K_{P}+\frac{K_{I}}{S}
$$

Therefore, the parameters of the PI controller are $K_{P}=$ 0.810525 and $K_{I}=32.421$.

The step response for the system is shown in Figure 10.

\section{Fractional Open Circuit Algorithm Based MPPT}

The variation in voltage and maximum power point is associated with the unpredictable solar irradiation and ambient temperature. The approximated voltage at maximum power point is a fraction of the open circuit voltage. The fraction open circuit voltage method is based on the following formula:

$$
V_{\mathrm{MPP}}=K * V_{\mathrm{oc}} \text {. }
$$

Figure 11 shows the block diagram implementation of PI controller in Matlab/Simulink. 


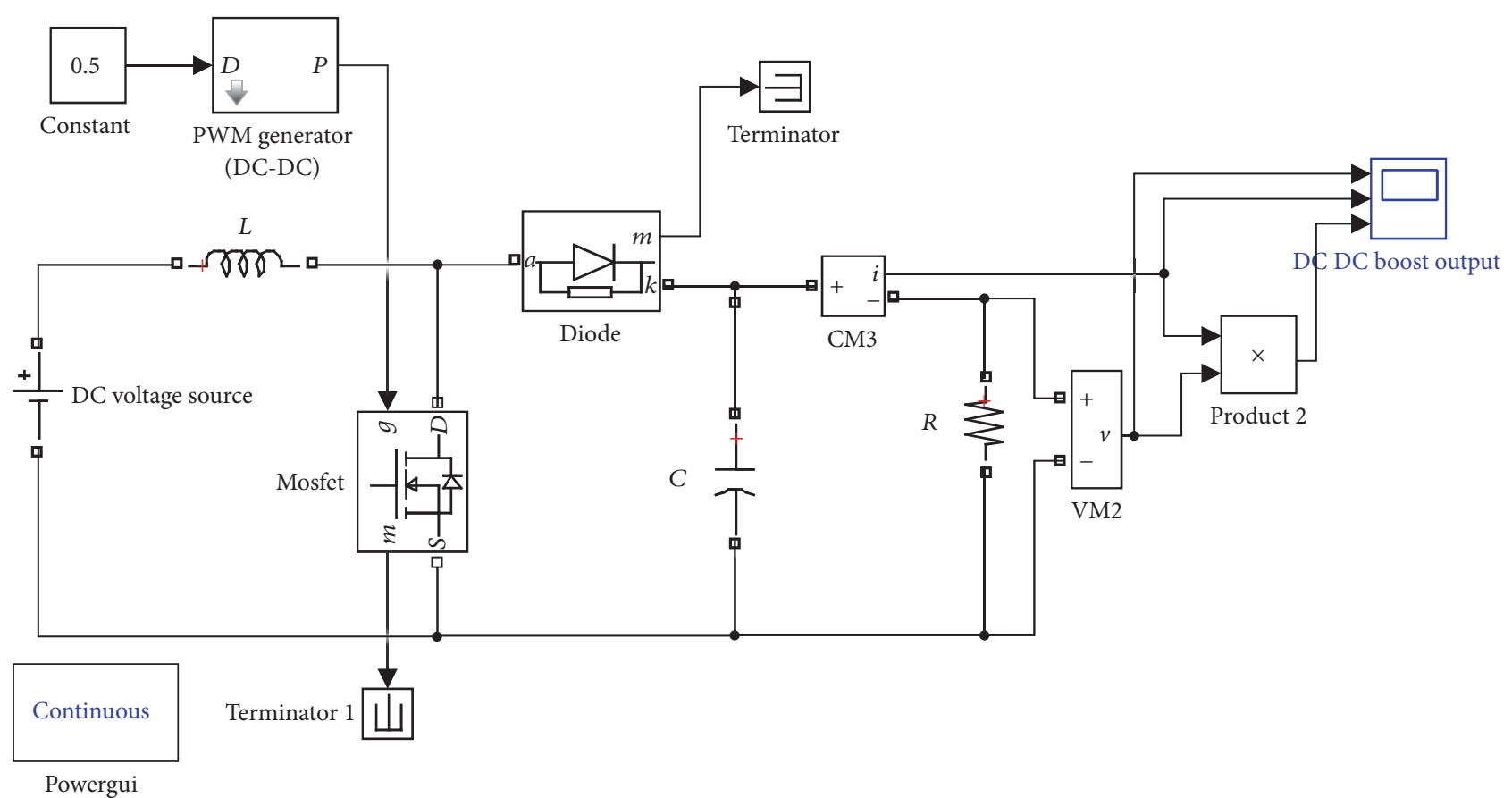

FIGURE 9: DC-DC boost converter Matlab/Simulink.

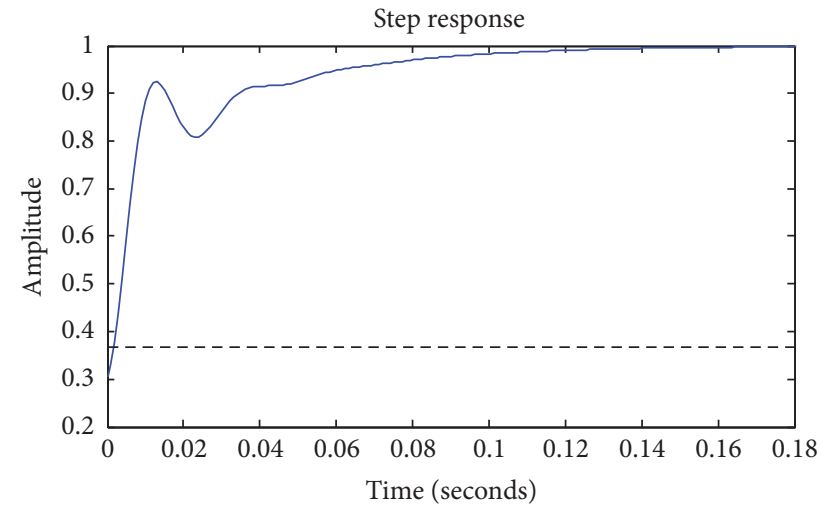

FIGURE 10: Step response of the system.

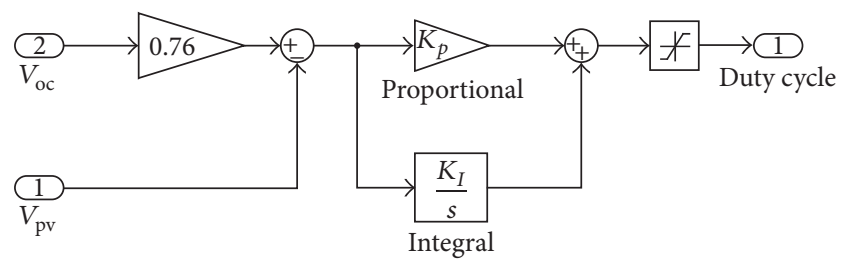

FIGURE 11: PI controller implementation in Matlab/Simulink.

Factor $K$ in (16) is less than a unity, and it varies according to the solar irradiation and ambient temperature. The variation of factor $K$ is between 0.71 and 0.8 , but the commonly used value for this factor is 0.76 .

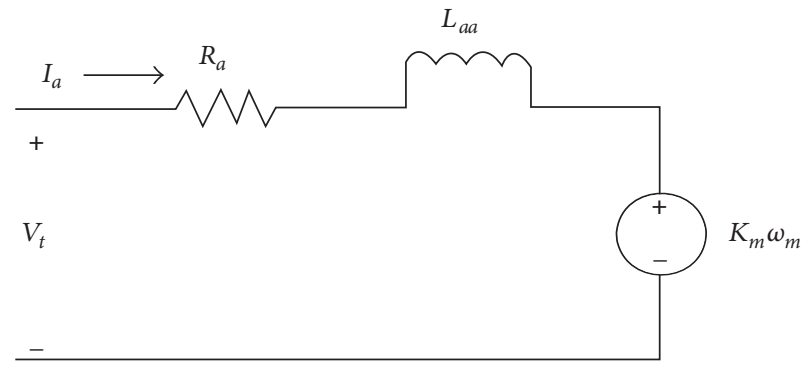

FIGURE 12: Equivalent circuit of a permanent magnetic DC motor.

\section{Permanent Magnetic PMDC Motor Model}

In PMDC motors, the field winding is permanent magnetic, so the PMDC motors do not need an external excitation. Figure 12 shows the equivalent circuit of a PMDC motor.

From Figure 12, the terminal voltage $\left(V_{t}\right)$ can be written as

$$
V_{t}=I_{a} * R_{a}+L_{a a} * \frac{d I_{a}}{d t}+k_{m} * \omega_{m}
$$

where $V_{t}$ is the DC source voltage $(\mathrm{V}), I_{a}$ is the armature current (A), $R_{a}$ is the armature resistance $(\Omega), L_{a a}$ is the armature inductance $(\mathrm{H}), k_{m}$ is the torque constant $(\mathrm{V} \cdot \mathrm{s} / \mathrm{rad})$, and $\omega_{m}$ is motor speed $(\mathrm{rpm})$. The electrical torque $T_{e}(\mathrm{~N} \mathrm{~m})$ is given by

$$
T_{e}=k_{m} * I_{a}
$$




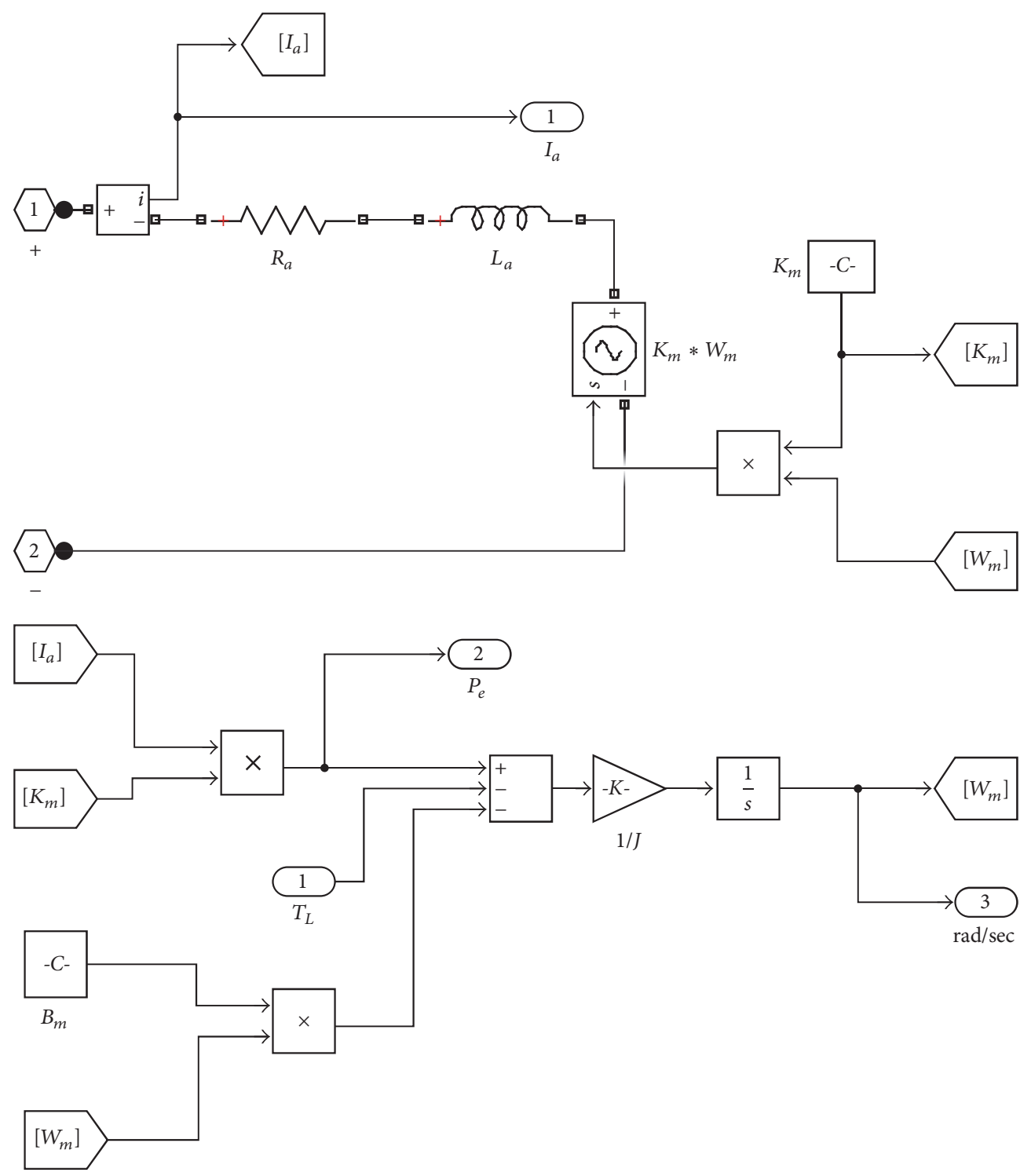

FIGURE 13: Detailed model of a permanent magnetic DC motor.

The motor speed as function in the electrical torque and the load torque $T_{L}(\mathrm{~N} \mathrm{~m})$ is given by

$$
J * \frac{d \omega_{m}}{d t}=T_{e}-T_{L}-B_{m} * \omega_{m}
$$

where $J$ is inertia constant $\left(\mathrm{kg} * \mathrm{~m}^{2}\right)$ and $B_{m}$ is constant $(\mathrm{N} *$ $\mathrm{m} * \mathrm{~s})$. By rearranging (17), (18), and (19), the dynamic model for a PMDC motor can be described as

$$
\begin{aligned}
\frac{d I_{a}}{d t} & =\frac{1}{L_{a a}} *\left(V_{t}-I_{a} * R_{a}-k_{m} * \omega_{m}\right), \\
\frac{d \omega_{m}}{d t} & =\frac{1}{J}\left(T_{e}-T_{L}-B_{m} * \omega_{m}\right) .
\end{aligned}
$$

Equation (20) can be implemented in Matlab/Simulink environment. Figure 13 shows the detailed model of a PMDC motor in Matlab.
A typical performance of a PMDC motor is shown in Figure 14. The highest efficiency can be achieved at a certain speed. Therefore, by controlling the PMDC motor speed, the PMDC can run efficiently.

The parameters for the PMDC motor are given in Table 5.

\section{Directly Coupled PV Water Pumping System with MPPT Based FOCV}

Figure 15 shows the Matlab model for the PV array connected directly to a permanent magnetic DC motor through a MPPT based FOCV method.

The Matlab model in Figure 15 is simulated and its power output for solar irradiance values $400 \mathrm{~W} / \mathrm{m}^{2}, 600 \mathrm{~W} / \mathrm{m}^{2}$, and $200 \mathrm{~W} / \mathrm{m}^{2}$ including initial transient is shown in Figure 16.

Figure 16 indicates that the fractional open circuit FOC based MPPT tracks the peak power from the PV array. 


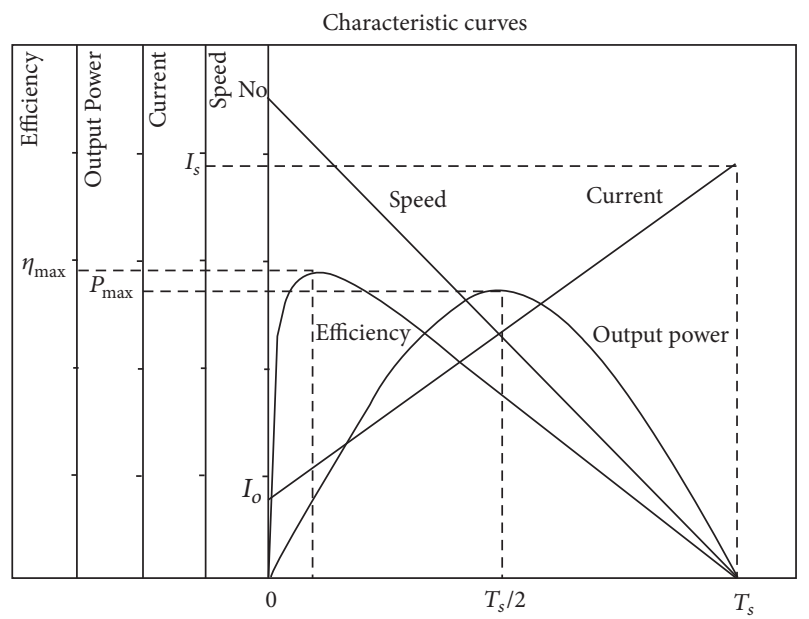

FIGURE 14: Typical torque versus speed, current, and power curves for a PMDC motor.

TABLE 5: PMDC motor parameters.

\begin{tabular}{lc}
\hline Parameters & Value \\
\hline Armature voltage $V_{t}$ & $105 \mathrm{~V}$ \\
Armature Current $I_{a}$ & $5.2 \mathrm{~A}$ \\
Armature resistance $R_{a}$ & $20 \Omega$ \\
Armature Inductance $L_{a}$ & $1.06 \mathrm{mH}$ \\
Moment of inertia $J$ & $\mathbf{1 . 0 6} * \mathbf{1 0}^{-\mathbf{6}} \mathrm{kg} \cdot \mathrm{m}^{2}$ \\
Viscous friction coefficient $B_{m}$ & $\mathbf{3 . 7 9} * \mathbf{1 0}^{-\mathbf{3}} \mathrm{N} \cdot \mathrm{m} \cdot \mathrm{s} / \mathrm{rad}$ \\
Constant $k_{m}$ & 0.52 \\
\hline
\end{tabular}

The input power to the PMDC motor is increased when the solar irradiance increases from $400 \mathrm{~W} / \mathrm{m}^{2}$ to $600 \mathrm{~W} / \mathrm{m}^{2}$. The input solar irradiation is increased at 0.32 seconds from $400 \mathrm{~W} / \mathrm{m}^{2}$ to $600 \mathrm{~W} / \mathrm{m}^{2}$. Since the PV array is directly coupled to the PMDC motor through a FOC based MPPT, the power causes an increase in the mechanical output torque. Since the torque is proportional to the armature current, the current at 0.32 seconds is increased as shown in Figure 16. In addition, the rotor speed of the PMDC motor is increased proportionally to the increase in the solar irradiation as shown in Figure 17. The flow rate of the centrifugal pump is increased as well due to the increase in the PMDC rotor speed. Figure 17 shows the increase of the flow rate when the solar irradiance is increased at 0.32 seconds.

However, the input power to the PMDC motor is decreased when the solar irradiance decreases from $600 \mathrm{~W} / \mathrm{m}^{2}$ to $200 \mathrm{~W} / \mathrm{m}^{2}$. The input solar irradiation is decreased at 0.48 seconds from $600 \mathrm{~W} / \mathrm{m}^{2}$ to $200 \mathrm{~W} / \mathrm{m}^{2}$. Since the PV array is directly coupled to the PMDC motor through a FOC based MPPT, the power causes a decrease in the mechanical output torque as shown in Figure 16. Because the armature current is proportional to the torque, the armature current is decreased as well. The rotor speed is decreased since the input power is decreased. This results in decreasing the flow rate are shown in Figure 17.
TABLE 6: Operating values for boost converter.

\begin{tabular}{lc}
\hline Parameters & Value \\
\hline Switching frequency $f$ & $25 \mathrm{KHz}$ \\
Inductance $L$ & $30 \mathrm{mH}$ \\
Capacitance $C$ & $80 \mu \mathrm{F}$ \\
Load resistance $R$ & $25 \Omega$ \\
\hline
\end{tabular}

\section{Controlling the PMDC Motor Input Voltage with Boost Converter}

To maintain the input voltage of the $0.5 \mathrm{hp}$ PMDC motor, an additional boost converter is connected between the storage system and the PMDC motor to maintain the input voltage constant. The parameters of the boost converter for this stage are shown in Table 6.

By using the state space averaging technique in (13), the PI controller is designed using SISO tools in Matlab/Simulink. The open loop transfer function of the converter and the parameters of the PI controller are given as

$$
H(s)=\frac{0.543 * S^{2}+271.5 * S+2.377 * 10^{5}}{S^{2}+500 * S+8.702 * 10^{5}} .
$$

Also, the parameters of the PI controller are given as

$$
\mathrm{PI}=K_{P}+\frac{K_{I}}{S} \text {. }
$$

Therefore, the parameters of the PI controller are $K_{P}=$ 0.23 and $K_{I}=115$.

The step response for the system is shown in Figure 18.

\section{Battery Stoarge System}

The charging control implementation in Matlab/Simulink is shown in Figure 19. Depending on the state of charge (SOC), the charging control works. The SOC contains a relay which opens when the battery reaches $95 \%$ of its charge. The SOC control does not allow the battery to be charged $100 \%$. In addition, when the discharge of the battery reaches $50 \%$, the battery is isolated from the load by opening its switch.

\section{Water Pump Model}

A centrifugal pump load is modeled by the following equation which indicates the load torque [11].

$$
T=4.8 * 10^{-6} * \omega^{2}+0.00019 * \omega+0.092 .
$$

The flow rate according to [12] can be given as

$$
Q=\frac{(\eta * P)}{(\rho * g * H)},
$$

where $(P)$ is the input power required $(\mathrm{W}),(\rho)$ is the fluid density $\left(\mathrm{kg} / \mathrm{m}^{3}\right),(H)$ is the energy head added to the flow $(\mathrm{m}),(\mathrm{g})$ is the standard acceleration of gravity $\left(9.80665 \mathrm{~m} / \mathrm{s}^{2}\right),(Q)$ is the flow rate $\left(\mathrm{m}^{3} / \mathrm{s}\right)$, and $(\eta)$ is the efficiency of the pump plant. 


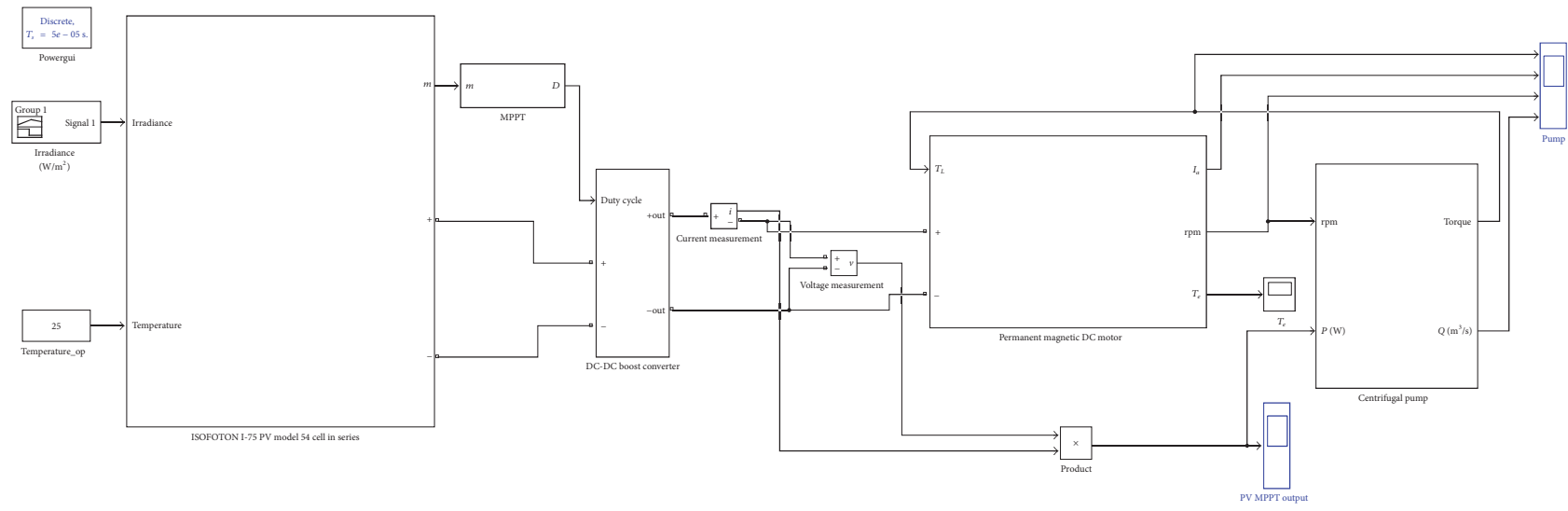

FIGURE 15: Directly coupled solar water pumping system model.
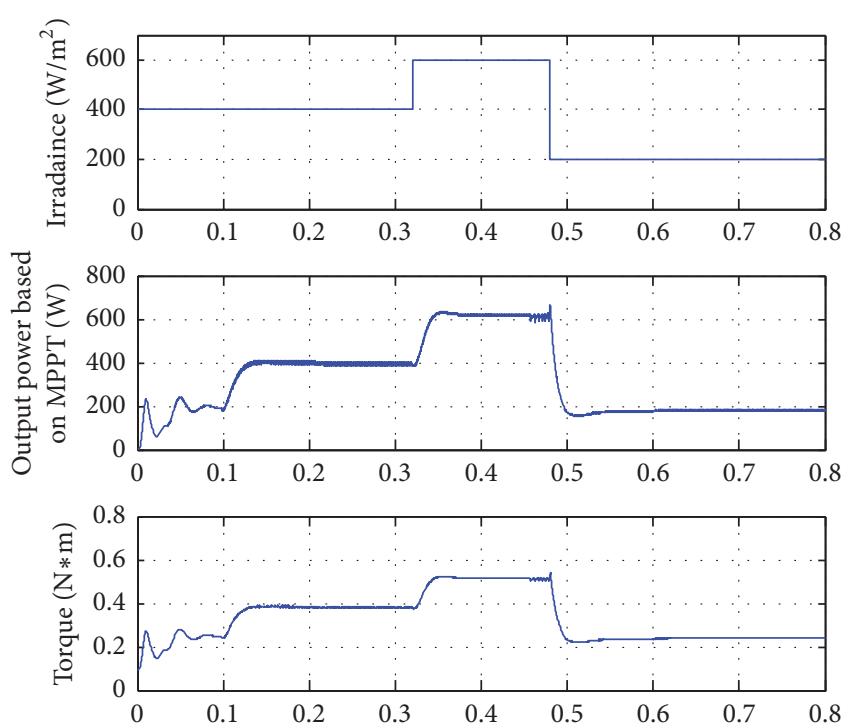

FIGURE 16: PV power and PMDC torque at various solar irradiation values.

\section{Solar Water Pumping System with MPPT Based FOCV and Battery Storage System}

The PV array model with charging battery controller has two effective components as shown in Figure 19. The battery storage with charging controller and boost converter to regulate the input voltage for the PMDC motor is added to the model as shown in Figure 20.

Figure 21 indicates the PV output peak power which is extracted by the FOCV Based MPPT method. The input solar irradiation is increased at 0.32 seconds from $400 \mathrm{~W} / \mathrm{m}^{2}$ to $600 \mathrm{~W} / \mathrm{m}^{2}$. Since the PV array is not directly coupled to the PMDC motor, the mechanical output torque remains constant because of the regulating boost converter as shown in Figure 18. Although the input solar irradiation is decreased at 0.48 seconds from $600 \mathrm{~W} / \mathrm{m}^{2}$ to $200 \mathrm{~W} / \mathrm{m}^{2}$, the mechanical torque remains constant due to the regulating boost converter as shown in Figure 21.
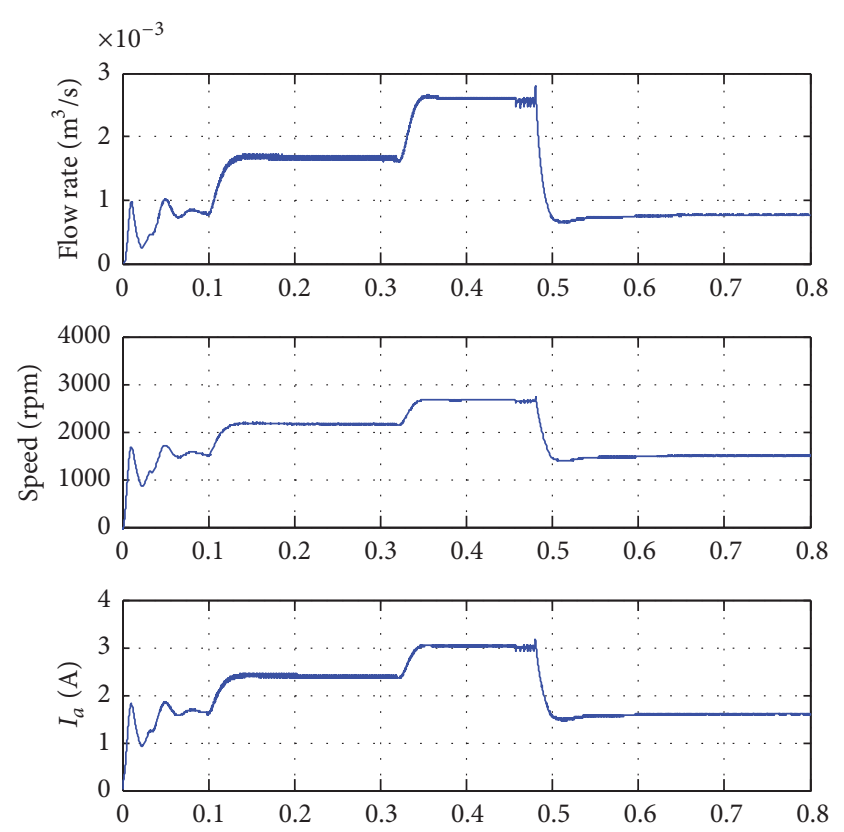

FIgURE 17: Flow rate, PMDC motor rotor speed, and armature current at various solar irradiation values.

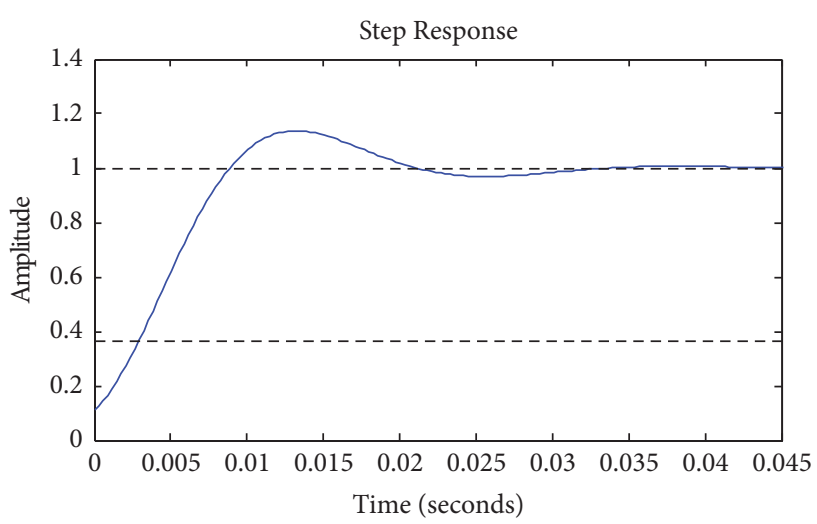

FIGURE 18: Step response of the system. 


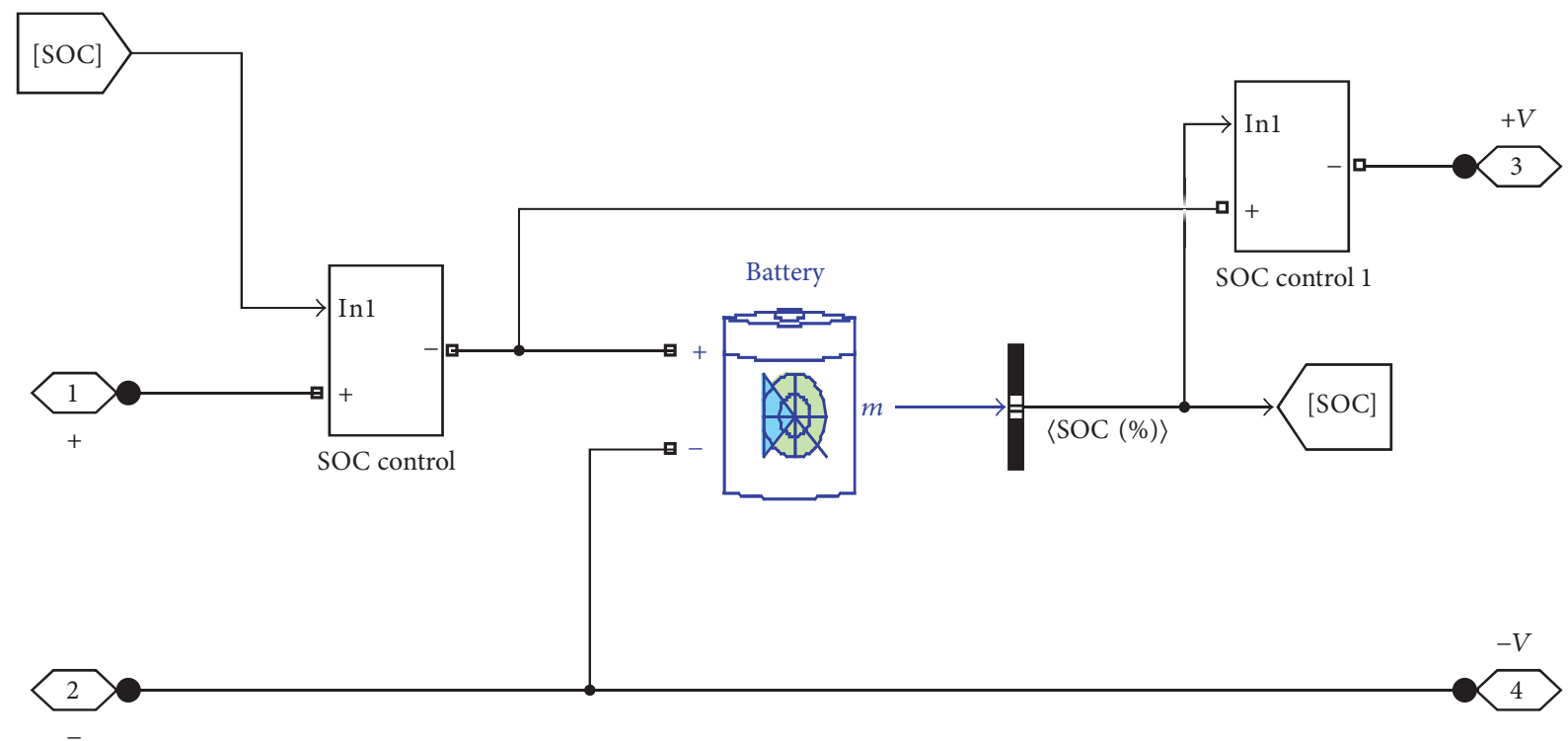

FIGURE 19: Battery charging controller.

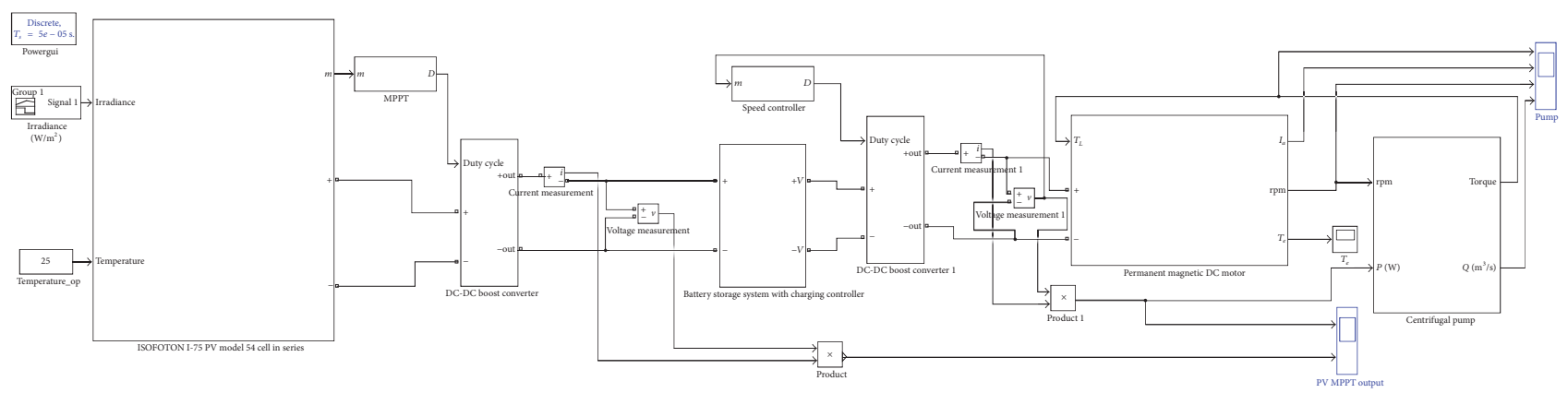

FIGURE 20: Solar water pumping system with battery storage system.
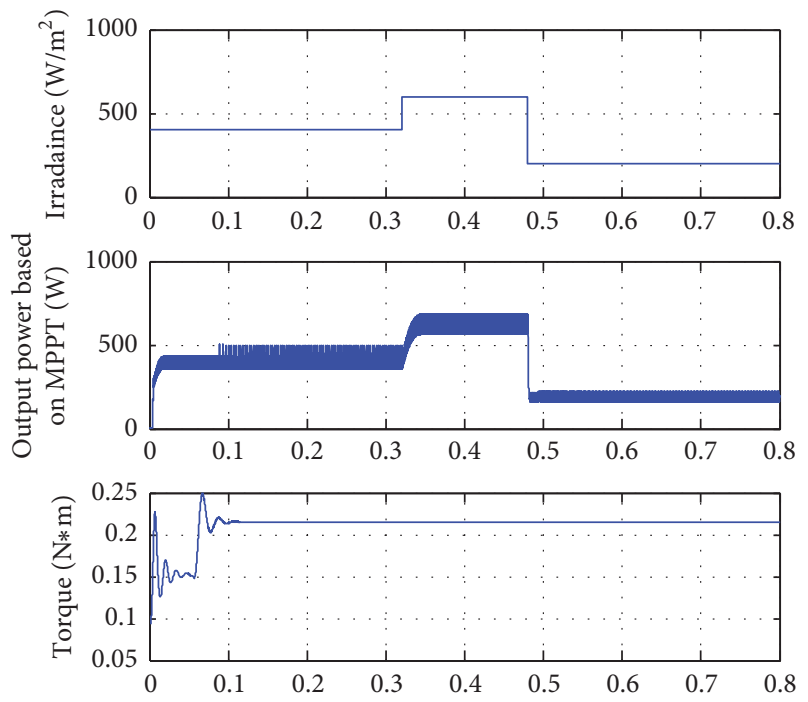

FIGURE 21: PV power and PMDC torque at various solar irradiation values.
The input power to the PMDC motor remains constant when the solar irradiance increases from $400 \mathrm{~W} / \mathrm{m}^{2}$ to $600 \mathrm{~W} / \mathrm{m}^{2}$. Because of the boost converter connected between the battery and PMDC motor, the input voltage is controlled by the boost converter. This makes the PMDC motor run at constant speed with different solar irradiation values. As a result of regulating boost converter, the rotor speed, the flow rate, and the armature current remain constant when the input solar irradiation is varying. This allows the PMDC motor to run at a constant speed with various solar irradiation values as shown in Figure 22. Initial simulation transient is also shown.

The added stage (Battery Storage and Regulation Boost Converter) controls the input power to the PMDC motor. Figure 18 shows that the solar irradiation is varying at 0.32 seconds and at 0.48 seconds. At 0.32 seconds, the solar irradiation is changed from $400 \mathrm{~W} / \mathrm{m}^{2}$ to $600 \mathrm{~W} / \mathrm{m}^{2}$ and it is changed at 0.48 seconds from $600 \mathrm{~W} / \mathrm{m}^{2}$ to $400 \mathrm{~W} / \mathrm{m}^{2}$. However, the input power to the PMDC motor remains 

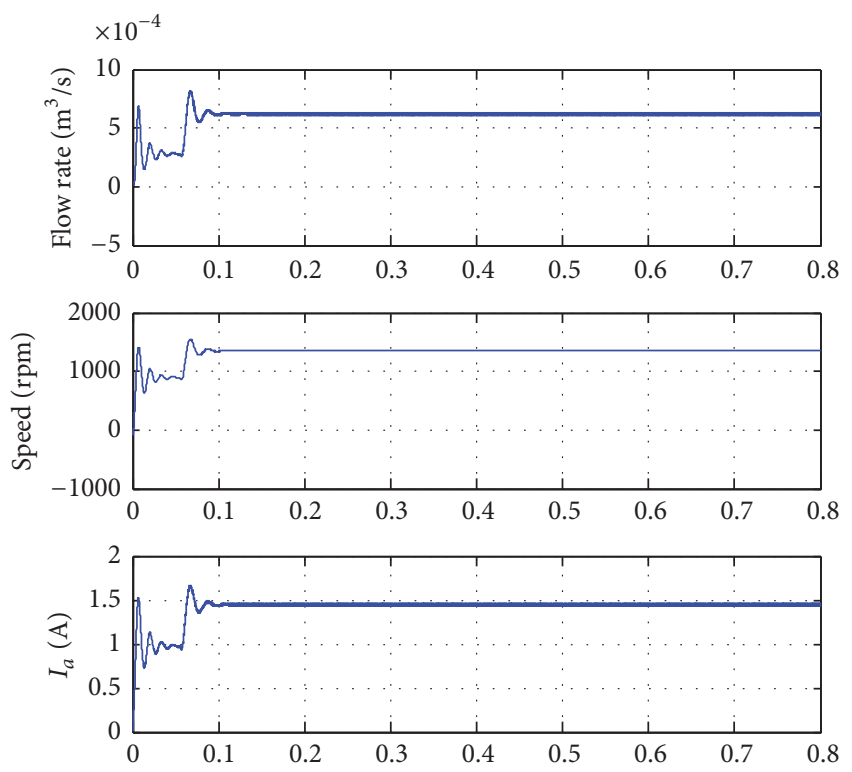

FIGURE 22: Flow rate, PMDC motor rotor speed, and armature current at various solar irradiation values.
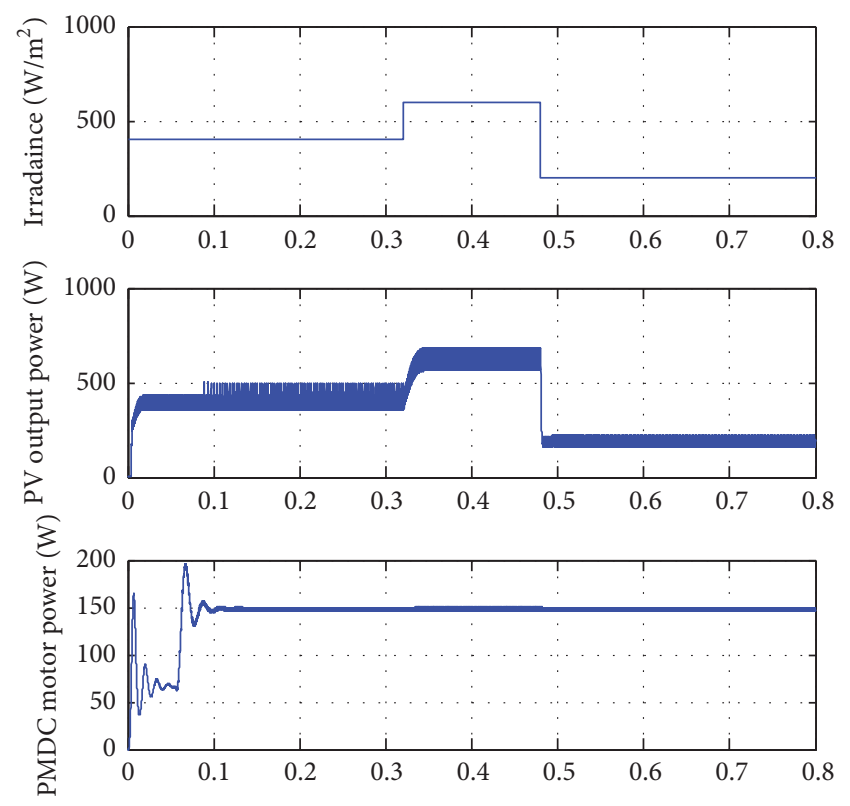

FIGURE 23: Peak extracted power from PV and PMDC input power at various solar irradiation values.

constant as shown in Figure 23 due to the regulating boost converter.

A part of the generated power by the PV array drives the PMDC motor which drives the centrifugal pump load, and the rest of the generated power by the PV array charges the battery. The charging controller is closed when the state charge percentage of the battery is less than $95 \%$. The solar irradiance is changed from $400 \mathrm{~W} / \mathrm{m}^{2}$ to $600 \mathrm{~W} / \mathrm{m}^{2}$ at 0.32 seconds. At 0.32 seconds the PV array output power becomes higher. This increases the rate of charging for the battery as shown in Figure 24. State of charge at 0.32 becomes faster

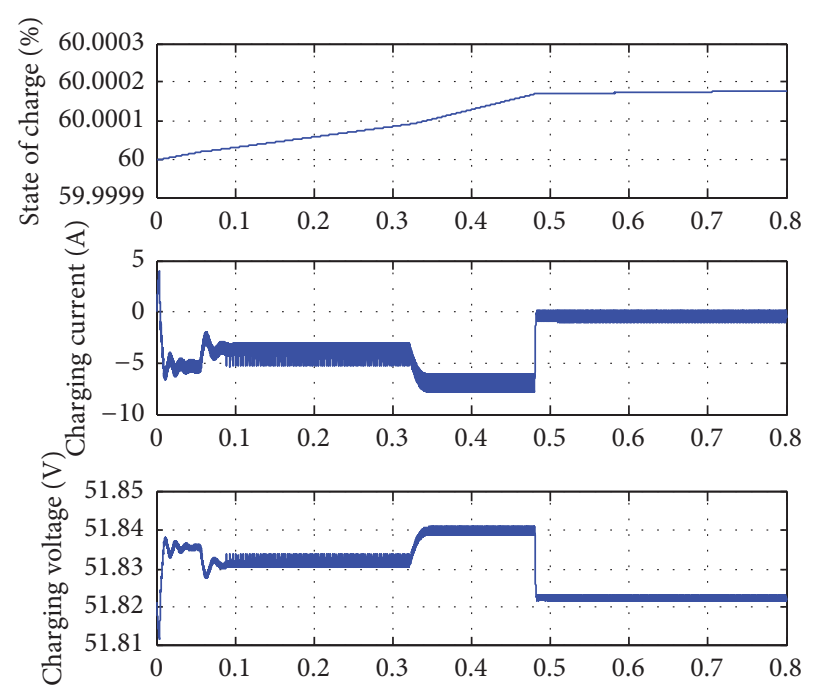

FIGURE 24: Battery state of charge at various solar irradiation values.

since the charging current and voltage become larger. However, when the solar irradiance is decreased from $600 \mathrm{~W} / \mathrm{m}^{2}$ to $200 \mathrm{~W} / \mathrm{m}^{2}$ at 0.48 seconds, the battery is slightly charged because the highest percentage of the PV output power goes directly to the PMDC motor. As shown in Figure 23, at 0.48 the charging current is small.

\section{Discussion and Conclusion}

The directly coupled solar water pumping system with MPPT and the solar water pumping system with battery storage through MPPT are modeled and simulated in Matlab/Simulink environment. The results are obtained from the simulation. For directly coupled solar water pumping system, the rotor speed, flow rate, and armature current are proportional to the solar irradiation. They vary according to the variation in the solar irradiation. This makes the performance of a PMDC less efficient since the efficiency of PMDC motor is a function of rotor speed. The highest efficiency of a PMDC motor can be achieved at one speed according to its characteristic curves. In addition, according to the demand of water, the input power cannot exceed the rated power of the PMDC motor. This leads to an increase in the hp rating of the chosen PMDC motor which is a function of the capital cost. Furthermore, water storage system (tank) needs to be bigger since the extra power will be stored as water for the next day. This leads to an increase in the capital cost of having bigger water tank. On the other hand, the solar water pumping system with battery storage and regulating boost converter leads to an efficient system because the system can be run at a specific speed. This allows the PMDC motor to be run at higher efficiency. The battery storage can be used to store the extra power for a few cloudy days which makes the system more reliable. The motor can be chosen with lower hp rating power which means lower capital cost and the storage water tank can be smaller in comparison to the directly coupling solar water pumping system. Although 
the battery storage and the extra converter can increase the capital cost, the efficiency and reliability of the solar water pumping system with battery storage and regulating boost converter are comparative.

The solar water pumping system with battery storage and regulating boost converter is an efficient and reliable system in comparison to directly coupling water pumping system. This is due the advantage of running the system at one speed which allows higher efficiency of PMDC motor, lower PMDC motor hp rating, and smaller water tank system.

\section{Conflicts of Interest}

The authors declare that they have no conflicts of interest regarding the publication of this paper.

\section{Acknowledgments}

The authors would like to thank the Libyan Government for funding this research.

\section{References}

[1] W. Lawrance, B. Wichert, and D. Langridge, "Simulation and performance of a photovoltaic pumping system," in Proceedings of the International Conference on Power Electronics and Drive Systems, vol. 1, pp. 513-518, February 1995.

[2] A. F. Minai, A. Tariq, and Q. Alam, "Theoretical and experimental analysis of photovoltaic water pumping system," in Proceedings of the India International Conference on Power Electronics (IICPE '10), pp. 1-8, January 2011.

[3] N. Chandrasekaran and K. Thyagarajah, "Simulation and experimental validation of AC motor and PMDC motor pumping system fed by photovoltaic cell," Indian Journal of Engineering and Materials Sciences, vol. 21, no. 1, pp. 93-103, 2014.

[4] N. Chandrasekaran, B. Ganeshprabu, and K. Thyagarajah, "Matlab based comparative study of photovoltaic fed DC motor and PMDC motor pumping system," ARPN Journal of Engineering and Applied Sciences, vol. 7, no. 5, pp. 543-547, 2012.

[5] M. Dubey, S. Sharma, and R. Saxena, "Solar PV stand-alone water pumping system employing PMSM drive," in Proceedings of the IEEE Students' Conference on Electrical, Electronics and Computer Science (SCEECS '14), Bhopal, India, March 2014.

[6] S. Belliwali, A. Chakravarti, and A. B. Raju, "Mathematical modelling and simulation of directly coupled PV water pumping system employing Switched Reluctance Motor," in Proceedings of the IEEE PES Innovative Smart Grid Technologies-India (ISGT India '11), Kollam Kerala, India, 2011.

[7] A. B. Raju, S. Ramesh Karnik, and R. Jyoti, "Maximum efficiency operation of a single stage inverter fed induction motor PV water pumping system," in Proceedings of the 1st International Conference on Emerging Trends in Engineering and Technology (ICETET '08), pp. 905-910, Nagpur, India, July 2008.

[8] A. Oi, M. Anwari, and M. Taufik, "Modeling and simulation of photovoltaic water pumping system," in Proceedings of the 3rd Asia International Conference on Modelling Simulation, Bali, Indonesia, 2009.

[9] M. Kolhe, J. C. Joshi, and D. P. Kothari, "Performance analysis of a directly coupled photovoltaic water-pumping system," IEEE Transactions on Energy Conversion, vol. 19, no. 3, pp. 613-618, 2004.
[10] M. Boxwell, Solar Electricity, Greenstream Publishing, Coventry, UK, 2016, edition.

[11] M. Taoufik, H. Karima, S. Lassaad, and G. Abdessattar, "Photovoltaic water pumping system with three-level NPC inverter," International Journal of Engineering Sciences, vol. 3, no. 10, pp. 99-108, 2014.

[12] S. K. Gupta, M. R. Khan, and K. Jahan, "Modeling, Analysis and Control of Solar Water Pumping System," http://www .krishisanskriti.org/vol_image/10Sep201511091751.pdf. 


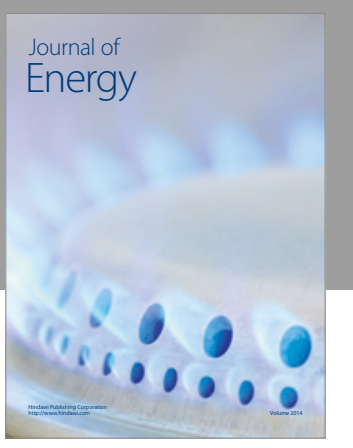

Journal of

Industrial Engineering
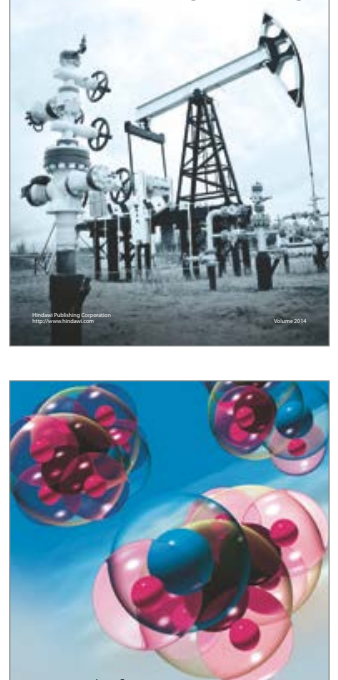

Fuels
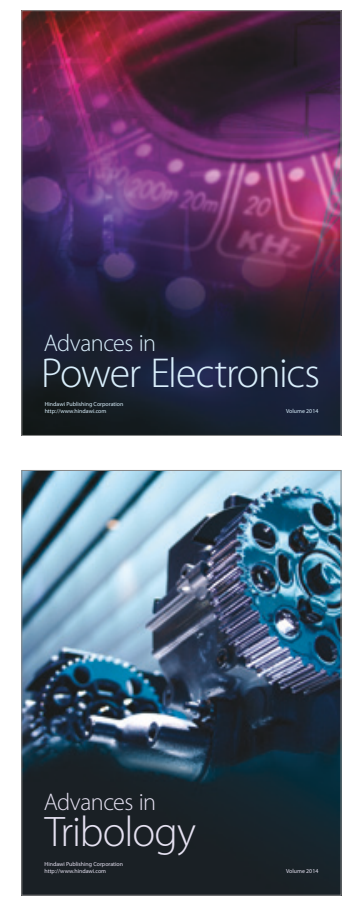
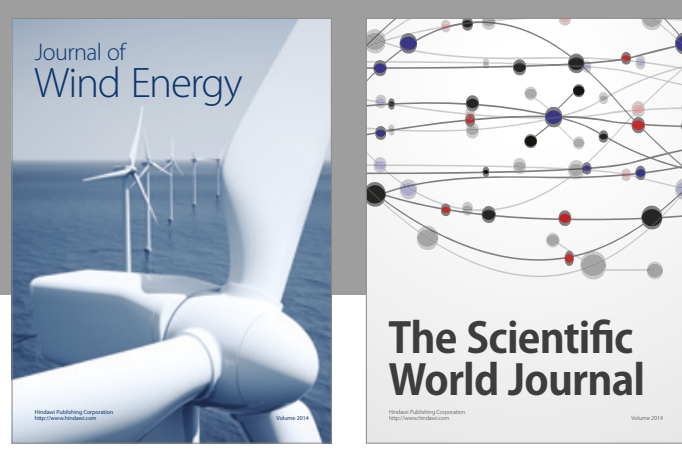

The Scientific World Journal
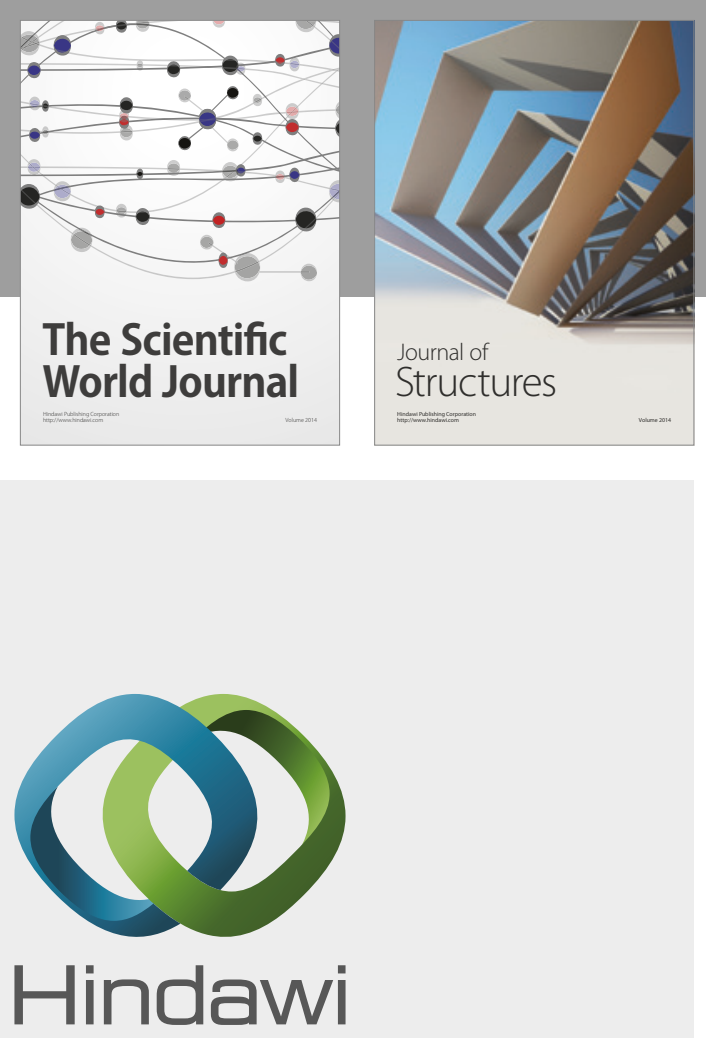

Submit your manuscripts at

https://www.hindawi.com
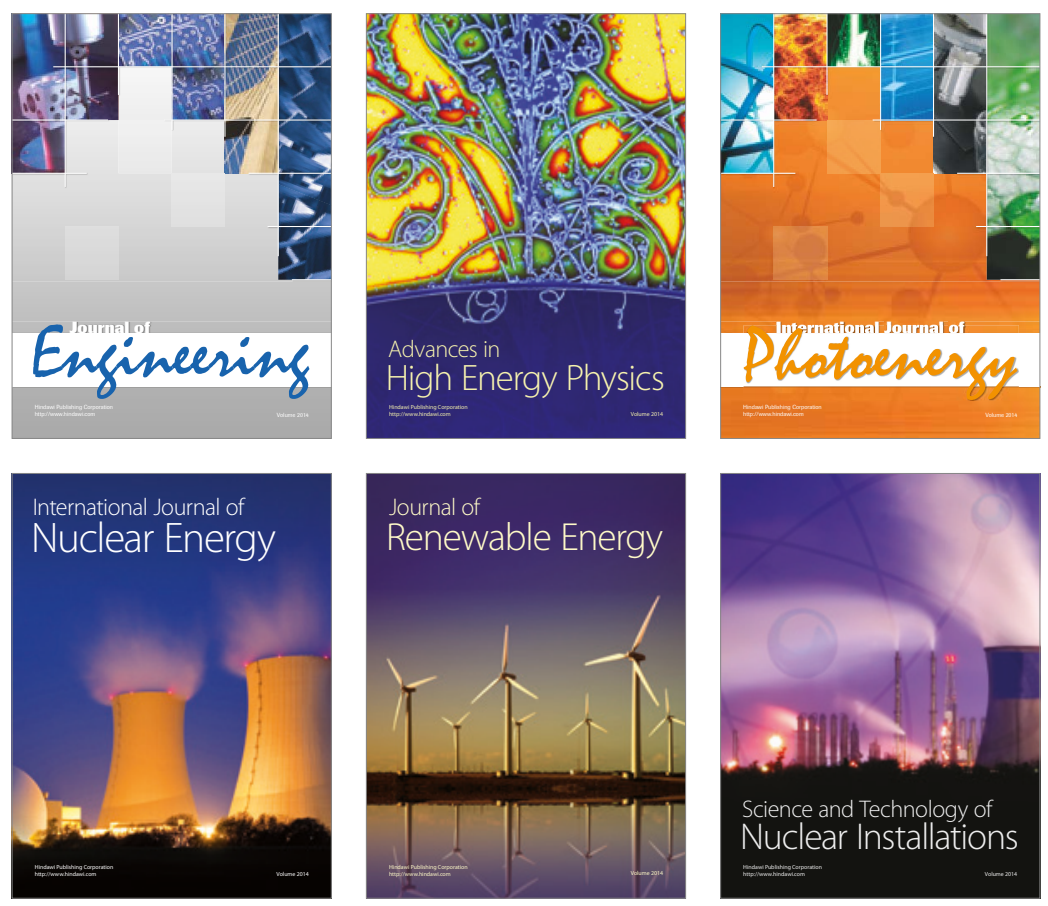

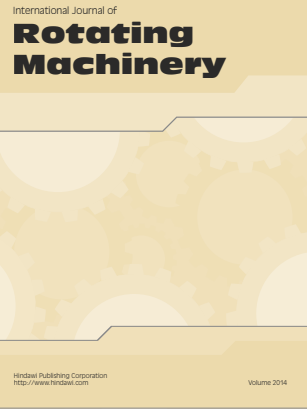

Journal of

Petroleum Engineering

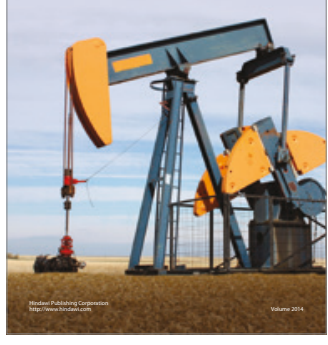

Journal of
Solar Energy
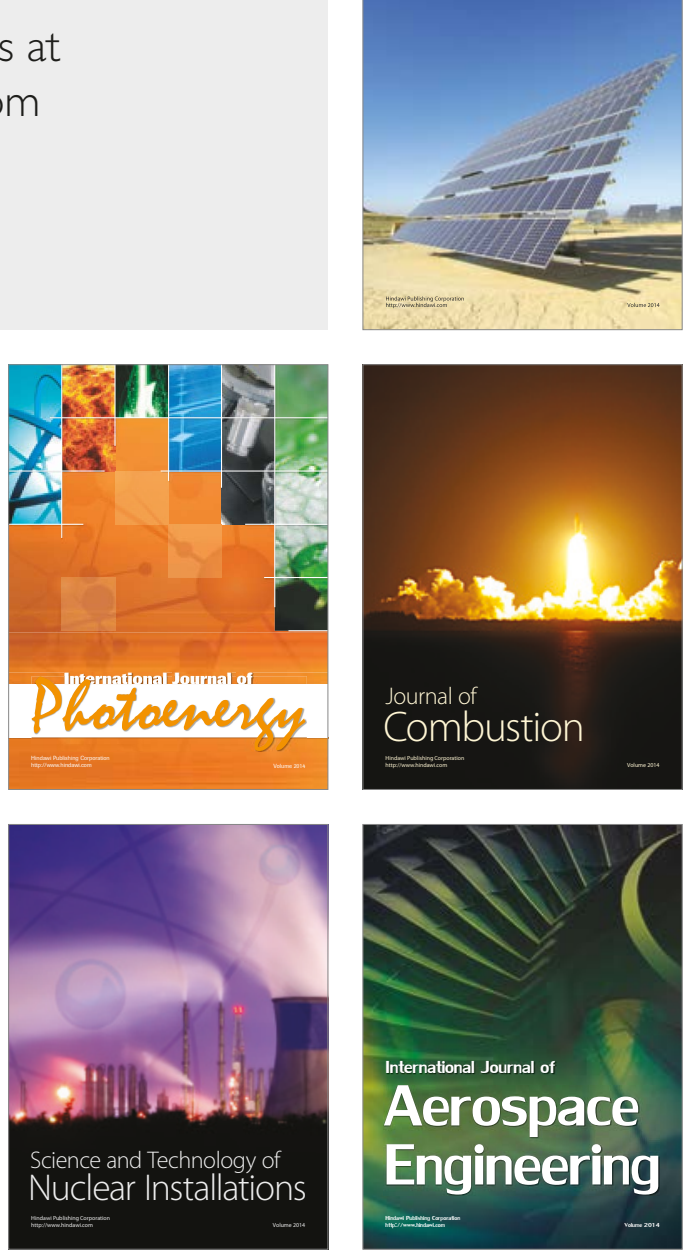